This is the author's manuscript of the article published in final edited form as:

Meek, J. A. (2015). Nurse Entrepreneur's Guide to Starting a Business. Clinical Nurse Specialist, 29(2), 78-79.

http://dx.doi.org/10.1097/NUR.0000000000000110

\title{
Nurse Entrepreneur's Guide to Starting a Business
}

\author{
Julie A Meek, PhD, RN, CNS \\ Clinical Associate Professor \\ Coordinator of DNP Program \\ Indiana University School of Nursing
}

Key words: Entrepreneurship; incorporation; business

Nurses have wonderful opportunities to become entrepreneurs. Nurses have great ideas spawned at the point of care as they experience subpar products and services and then envision how those products or services could be improved. Quite literally, the business I started was in direct response to my experiences as an Emergency Department nurse. So many of the people I cared for, if they had been found and helped earlier, could have avoided their acute crisis. That became my business mantra...finding and helping people early. That mantra led to the development of a patented predictive model to identify high-risk individuals as well as an evidence-based telephonic health coaching intervention. After taking that idea through the rigorous evaluation afforded by solid business planning, the next step was to incorporate the business.

There are many things to consider when forming a business. While not intended to take the place of sound legal counsel, the following are some important considerations.

\section{Choosing a structure for your business}

It's very important to consult an attorney for assistance with this step, as each business structure has both legal, and tax implications. The structure for the business needs to fit the nature of the business, ownership structure, and desired legal/financial protections. States have small business websites offering descriptions of available structures ranging from informal associations such as sole proprietorships and general partnerships to far more 
formalized structures such as corporations (C-corp), S corporations (S corp), limited liability companies (LLC), nonprofit corporations, limited partnerships (LP), and limited liability partnerships (LLP). ${ }^{1}$

If forming a corporation, one must issue shares of stock. Shares represent ownership of the corporation and the number of shares issued represents the percentage ownership of each partner in the business. The corporation, itself, owns the assets, not the founders. Therefore, it is important to consult legal counsel to determine the number of authorized shares to issue. For example, a corporation may be authorized to issue 1,000 shares, but only issue 200. It is important that all owners be issued their shares of stock upon incorporation of the business and this initial stock issuance is often called "founder's stock".

There is another incredibly important concept called "the corporate veil". It is important to treat the corporation or formal association as a separate and distinct entity. Failure to treat the corporation as a separate entity may allow a creditor to pierce the corporate veil and subject a shareholder's personal assets, such as bank accounts and other property, to the satisfaction of the debts and liabilities of the corporation. Evidence that the owners are treating the corporation like a corporation includes, among other corporate acts, issuing stock certificates which represent share ownership, electing directors and officers, filing the biennial report, keeping annual shareholder meeting minutes and maintaining a corporate bank account and financial records. So structures and processes for each of these corporate acts and for corporate record keeping need to be initiated upon business start-up.

\section{Selecting a name for the business}

It may sound easy, but often, selecting a name for a business can be quite difficult. Most state laws require that that the name of a Corporation, LLC, LP, and an LLP must be distinguishable from the names of other businesses of the same type on the records of the Secretary of State's office. There are typically websites and/or state offices that can check the availability of potential names. In addition to the legal requirements, the name of the business is a key branding choice, so should be decided with care. 


\section{Actually forming the business}

Once a structure for the business has been chosen, the next step is actually forming the business. All states require submission of the proper organizational documents and fees to the Secretary of State's office. Often called "articles of incorporation", the form of these organizational documents are specific to each type of business structure, but again, most states have such forms available from their Secretary of State's website. Once filed and the fee paid, the articles of incorporation document should be stored safely and securely as it's the official record the business' existence.

\section{Other important start-up considerations}

There are a number of other important start-up considerations. Following incorporation, each business must obtain an Employer Identification Number (EIN) from the IRS. ${ }^{2}$ This EIN is the federal tax identification number used to impose federal taxes. If the business has employees, there are a wide range of obligations for the protection and provision for employees from payroll taxes, to environmental protections, to important human resource policies to consider. Most states also have workforce development sites that can provide helpful information to help guide an entrepreneur through these obligations. ${ }^{3}$

In addition, it is very important to immediately set up a separate bank account, credit card, and accounting system for the business. Accounting software systems are fairly easy to use and facilitate invoicing, managing receivables, calculating payroll taxes, and most importantly, generating financial reports. Maintaining accurate "books" for the business is an imperative and financial reports should be viewed as tools to help manage the business.

Finally, making decisions about who will comprise the business' board of directors and officers is also a very important decision as the management of the business reports to and serves at the pleasure of the board of directors. The board of directors is voted upon by the company's shareholders to represent their interests, so ultimately the shareholders and board of directors control the business. All of these actions establish the "corporate veil" so important to the protections available through the corporation. 
Let the fun begin!

Starting your own business requires a lot of up front business planning, strategic thinking, and just plain hard work. But once you have satisfied the start-up requirements, it's time to enjoy some of the more pleasant aspects of starting a business. Start-up tasks also include the development of your "brand" in terms of your company name's logo, logotype, business cards, and business paper accoutrements. Your brand will also appear to all the world via your website, so hiring the right expertise to not only build your website, but also to position your site highly on search engines is a must if your business is dependent on web exposure.

The business may or may not initially require space to operate. If it does, then negotiating a lease is also another important start-up consideration. Lease terms vary widely, so it's important to seek guidance from a knowledgeable advisor to read the fine print of the lease to assure the greatest protections and flexibility as your business moves forward, looking both to the ramifications of growing beyond the leased space as well as business failure and the ramifications therein to fulfill the lease obligation.

As shared in prior columns, it's also fun and so important to begin to establish the business' esprit de' corp! $!^{4}$ Not only is it fun to team with initial employees to start-up your business, indeed it's a business imperative to pay attention to the lived experience of being an employee of the business. One of the most valued parts of an entrepreneur's journey is sharing the hard work, the disappointment, and the victories with a great team of colleagues. Putting incentives, communication, and decision making practices in place that foster shared trust, dialogue and input provides employees with a true sense of ownership in the business and its success.

In closing...

Starting a business is hard work. It requires thoughtful, persistent and well-advised actions, and the assurance of adequate time, money, and talent resources to give a business the best possible chance of success. Yet the rewards are like none other. The satisfaction that comes with pursuing one's passion and truly making a difference can make it all worth it! Nurses have great ideas and have the opportunity to turn those ideas into successful and profitable businesses. 
References:

1) IN.gov. An entrepreneur's guide to starting a business in Indiana. Retrieved Nov 15, 2014 from http://www.in.gov/sos/business/2428.htm

2) Internal Revenue Service. Federal EIN Application. Retrieved Nov 15, 2014 from www.irs-ein-number.com/

3) Department of Workforce Development. IN.gov. Retrieved Nov 15, 2014 from http://www.in.gov/dwd/

4) Meek, J.A. (2014, July/August). Nurse Entrepreneur: Aligning shared responsibilities with shared rewards to create an effective work culture. Clinical Nurse Specialist, 28(4), 1-3. doi: 10.1097/NUR.0000000000000060 